Tropical Journal of Pharmaceutical Research October 2020; 19 (10): 2109-2114

ISSN: $1596-5996$ (print); 1596-9827 (electronic) (C) Pharmacotherapy Group, Faculty of Pharmacy, University of Benin, Benin City, 300001 Nigeria.

\title{
Evaluation of anti-inflammatory and antioxidant activities of Sedum sediforme extracts
}

\author{
Hayat Trabsa ${ }^{1,2}$, Imane Krach ${ }^{1}$, Naouel Boussoualim ${ }^{1}$, Soraya Ouhida ${ }^{3}$, \\ Lekhmici Arrar ${ }^{1}$, Abderrahmane Baghiani ${ }^{1}$ \\ ${ }^{1}$ Laboratory of Applied Biochemistry, Faculty of Nature and Life Sciences, Univ. Setif, Setif 19000, ${ }^{2}$ Faculty of Exact Sciences \\ and Nature and Life Sciences, University of Biskra, Biskra 07000, ${ }^{3}$ Faculty of Medicine, Univ. Setif, Setif 19000, Algeria \\ *For correspondence: Email: hayat.trab@yahoo.fr; Tel: +213-675368146
}

\begin{abstract}
Purpose: To evaluate the in vivo anti-inflammatory effect and in vitro antioxidant activity of the areal part of Sedum sediforme (Jacq.) extracts.

Methods: The plant was extracted with solvents of varying polarity (Methanol, chloroform and ethyl acetate, respectively) allowed its separation into three sub-fractions: crude extract, chloroform extract and ethyl acetate extract (CrE, ChE and EaE, respectively). Total polyphenol contents of the extracts were determined. The phorbolmyristate acetate (PMA) induced mice ear edema method was using to evaluate the anti-inflammatory activity. The in vitro scavenging activity was evaluated using enzymatic and non-enzymatic methods. Chelating ability of extracts was assessed using $\mathrm{Fe}^{2+}$-ferrozine complex. Results: The highest content of phenolics compound was in EaE. The administration of CrE (12.5 and $25 \mathrm{mg} / \mathrm{kg}$ ) reduced ear edema induced by PMA (\%l $=35.81 \pm 3.18 \%$ and $38.57 \pm 2.80 \%$, respectively), the effect was comparable with that of diclofenac used as a reference drug $(\% l=38.84 \pm 1.87 \%)$. The in vitro scavenging activity of S. sediforme extracts confirmed that the CrE has the highest enzymatic and non-enzymatic activity with a half maximal inhibitory concentration (IC50) $=0.063 \pm 0.005 \mathrm{mg} / \mathrm{mL}$ and $0.178 \pm 0.006 \mathrm{mg} / \mathrm{mL}$, respectively. However, the ChE present an excellent chelating activity with a half-maximal effective concentration (EC 50 ) of $0.397 \pm 0.001 \mathrm{mg} / \mathrm{mL}$.

Conclusion: The results show that $S$. sediforme extracts have a strong antioxidant and antiinflammatory activities which lend some support their use in the traditional medicine.
\end{abstract}

Keywords: Sedum sediforme, Anti-inflammatory, Superoxide scavenger, Cytochrome C, Metal chelating

This is an Open Access article that uses a fund-ing model which does not charge readers or their institutions for access and distributed under the terms of the Creative Commons Attribution License (http://creativecommons.org/licenses/by/4.0) and the Budapest Open Access Initiative (http://www.budapestopenaccessinitiative.org/read), which permit unrestricted use, distribution, and reproduction in any medium, provided the original work is properly credited.

Tropical Journal of Pharmaceutical Research is indexed by Science Citation Index (SciSearch), Scopus, International Pharmaceutical Abstract, Chemical Abstracts, Embase, Index Copernicus, EBSCO, African Index Medicus, JournalSeek, Journal Citation Reports/Science Edition, Directory of Open Access Journals (DOAJ), African Journal Online, Bioline International, Open-J-Gate and Pharmacy Abstracts

\section{INTRODUCTION}

Inflammation is the primary reaction of the immune system to infection or tissue injury, main to safety of the human body in opposition to those insults. Prolonged or chronic inflammation is harmful and has a very important role within the development of diseases such as Alzheimer's, arthritis, cardiovascular disease and diabetes [1]. Acute inflammation, which is described by pain, heat, redness and swelling includes many series of events including 
increased permeability, vasodilatation, fluid exudation and migration of leukocytes. In an inflammatory environment, a massive quantities of superoxide radical and different free radicals was produced by activated neutrophils and macrophages via the $\mathrm{NAD}(\mathrm{P}) \mathrm{H}$ oxidase. Similarly, free radicals created in inflammation might also lead to toxic effects once produced at high levels during oxidative burst [2]. The offered anti-inflammatory medicaments (steroidal and non-steroidal) present wide side effects. Consequently, many researches were devoted to the look for a new anti-inflammatory agent from herbal sources. Medicinal components from plants play important role in conventional traditional medicine, Sedum species are the home of traditional remedies that are mostly used as hypotensive, laxative and emetic and anti-inflammatory agents [3]. Sedum sidiforme is among the medicinal plant used in Algeria. The aim of this study is to evaluate the antiinflammatory, superoxide scavenger and metal chelating activity of Sedum sediforme extracts.

\section{EXPERIMENTAL}

\section{Materials}

Sedum sediforme was collected from N'Gaous, Batna (Algeria) Algeria, at the end of March 2012 (between 12.00- $14.00 \mathrm{~h}$ ), and identified by Professor Oudjhih Bachir, Department of Agronomy, Batna University, Batna, Algeria. A voucher specimen was deposited in an official herbarium of the same department (no. I.A.B./990) for future reference. All chemical reagents were purchased from Fluka, Sigma Chemicals, and Prolab (Germany).

Adult male mice were obtained from the Pasteur Institute of Algeria (weighting twenty-five - thirty g). Animals were kept on a 12-hour light/dark cycle and housed in cages (polycarbonate). The animals were transferred to the laboratory at least one week before the experiments. The animal experiments were performed in accordance with international guidelines for the use and care of laboratory animals [4]. Ethical approval for the animal experimentation was obtained from Ethics Review Committee of Faculty of Exact Sciences and Nature and Life Sciences, University of Biskra, Biskra, Algeria (approval ref no. 307/V.D.P.G.).

\section{Extraction of phenolic compounds}

The extraction was carried out using various polar and non-polar solvents, according to the method of Markham [5]. S. sediforme powder was soaked in methanol with a ratio of $1: 10 \mathrm{w} / \mathrm{v}$, under agitation overnight at $4{ }^{\circ} \mathrm{C}$. The extract was filtered to obtain the first filtrate, the solvent of this filtrate was removed under reduced pressure (Rotavapor: Germany, bÜchi461) below $45^{\circ} \mathrm{C}$ to obtain the methanol extract and it was coded as CrE. In order to obtain a general view of the plant compounds it can be use a non-polar to polar solvent scale liquid-liquid extraction of the CrE : hexane (defatting), chloroform (aglycone flavonoids extraction), and ethyl acetate (glycoside flavonoids extraction). The percolates were evaporated to give chloroform and ethyl acetate (ChE and EaE, respectively) extracts. All of these fractions were stored prior to use at $-20^{\circ} \mathrm{C}$.

\section{Determination of total phenolic content}

The Folin-Ciocalteu reagent was using to determine total phenolic content [6]. After incubation for $4 \mathrm{~min}$ of $200 \mu \mathrm{L}$ of diluted sample and $1 \mathrm{~mL}$ of diluted Folin-Ciocalteu reagent 1:10 (v/v), $800 \mathrm{~mL}$ of $\mathrm{NaCO}_{3}$ aqueous solution (75 $\mathrm{g} / \mathrm{L})$ was added. The absorbance measured at $760 \mathrm{~nm}$ after incubation ( $1 \mathrm{~h}$ at $25^{\circ} \mathrm{C}$ ). Gallic acid $(0.2-1 \mathrm{mg} / \mathrm{mL}$; Sigma) was used as the standard for the calibration curve, and total phenolic content was expressed as microgram gallic acid equivalent ( $\mu \mathrm{g}$ GAE)/mg extract.

\section{Evaluation of anti-inflammatory activity of CrE}

The method of Garrido et al [7] with slight modification, PMA was used to induce ear edema on the right ear of each mouse ( $4 \mu \mathrm{g} / \mathrm{ear}$ of, in $20 \mu \mathrm{L}$ of acetone). The left ear (control) of the same mouse received $20 \mu \mathrm{L}$ of the vehicle (acetone). The CrE of S. sediforme was injected 12.5 and $25 \mathrm{mg} / \mathrm{kg}$ body wt. in normal saline ( $\mathrm{D}_{1}$ and $D_{2}$, respectively) $1 \mathrm{~h}$ before PMA application. With a reference group treated with diclofenac (10 mg/kg body wt.) and an untreated group (control group). Mice were euthanized by cervical dislocation, 6 hours after PMA application, and a disc (6-mm diameter) was removed with a metal punch from each ear and weighed. Ear edema was calculated by according to the following equation:

Edema weight $=$ the weight of right disc (treatment) - the weight of the left disc (vehicle)

Inhibition percentage was expressed as the reduction in weight.

\section{Superoxide scavenging activity}

Enzymatic assay: Superoxide radical $\left(\mathrm{O}_{2}{ }^{-}\right)$ which generated by the xanthine/xanthine 
oxidase $(\mathrm{X} / \mathrm{XO})$ are able to reduce cytochrome $\mathrm{c}$. The effects of $S$. sediforme extracts on the generation of $\mathrm{O}_{2}$-- $^{-}$were determined according to the method of Selloum et al [8] by using a purified XO from bovine milk with specific activity of $2055.05 \mathrm{nmole} / \mathrm{min} / \mathrm{mg}$ of enzyme. Purification of bovine milk $\mathrm{XO}$ was carried out according to Baghiani et al [9]. The reaction mixture, in airsaturated phosphate buffer $(50 \mathrm{mM}, \mathrm{pH}$ 7.4) supplemented with EDTA $(0.1 \mathrm{mM})$, contained $100 \mu \mathrm{M}$ of xanthine (substract) and cytochrome c (25 $\mu \mathrm{M})$, and corresponding concentration of each extract (CrE, ChE and EaE) diluted in phosphate buffer. One min after the addition of enzyme, reduced cytochrome c was spectrophotometrically determined at $550 \mathrm{~nm}$ against blanc (enzyme-free mixture). The amount of generated superoxide was calculated using an extinction coefficient $\epsilon 550=21100 \mathrm{M}^{-1} \cdot \mathrm{cm}^{-1}$. The results are expressed as extract concentration that inhibits the reduction of the moiety amount of cytochrome c $\left(\mathrm{IC}_{50}\right)$.

Non-enzymatic Assay (NBT test): Superoxide radicals were generated by the PMS/NADH (phenazinemethosulfate/nicotinamide adenine dinucleotide) system according to the method described by Ani et al [10]. The reaction mixture consisted of $3 \mathrm{mM}$ of $\beta-\mathrm{NADH}$, varying concentrations of each $S$. sediforme extracts, 1 $\mathrm{mM}$ of nitrotetrazolium blue chloride (NBT) and $0.3 \mathrm{mM}$ of PMS. All samples were dissolved in phosphate buffer $0.1 \mathrm{M}, \mathrm{pH}$ 7.8. The reaction was conducted at $25^{\circ} \mathrm{C}$ (room temperature) for 2 min and initiated by the addition of PMS for 3 min. The variation of the absorbance at wavelengths of $560 \mathrm{~nm}$ was measured. Decrease in absorbance in the presence of various plants extracts indicated the superoxide scavenging activity. Superoxide quenching activity (\%) of was calculated as in Eq 1.

Superoxide quenching $(\%)=\left\{100\left(A_{c}-A_{s}\right) / A_{c}\right\}$ (1)

where $A_{c}$ is the control absorbance, and As is the absorbance in the presence of extracts. Evaluating the superoxide scavenging activity of extracts was based on $\mathrm{IC}_{50}$ (concentration required to cause a $50 \%$ inhibition).

\section{Evaluation of metal chelating activity}

The chelating of $\mathrm{Fe}^{2+}$ (ferrous ions) by plant extracts was estimated as described by Le et al [11]. Briefly, different concentrations of $S$. sediforme extracts were added to a $0.05 \mathrm{~mL}$ $\mathrm{FeCl}_{2}$ solution $(0.6 \mathrm{mM})$ and left for incubation at $25{ }^{\circ} \mathrm{C}$ for $5 \mathrm{~min}$. The reaction, left standing at 25 ${ }^{\circ} \mathrm{C}$ for $10 \mathrm{~min}$, after adding of ferrozine $(0.1 \mathrm{~mL}, 5$
$\mathrm{mM}$ ). Absorbance was then measured spectrophotometrically at $562 \mathrm{~nm}$ and the percentage of ferrous iron-chelating effect was calculated using Eq 2.

Ferrous iron-chelating effect $(\%)=\left\{100\left(A_{c}-\right.\right.$ $\left.\left.A_{s}\right) / A_{c}\right\}$

where $A_{c}$ is the control absorbance of all samples without extracts, and $A_{s}$ is the absorbance in the presence of extracts or EDTA as reference chelators. The effective concentration which produce $50 \%$ of $\mathrm{Fe}^{2+}$ ions chelating $\left(\mathrm{EC}_{50}\right)$ was calculated.

\section{Statistical analysis}

The results are expressed as mean \pm SD or SEM. Wherever applicable, the results were subjected to ANOVA (one-way analysis of variance), Dunnett's and multiple comparison test used to compare between extracts and standards, where the variations between extracts to each other were determined by Tukey's multiple comparison test, using GraphPad program, $p$ value $\leq 0.05$ was considered as significant.

\section{RESULTS}

\section{Total phenolic content}

The content of polyphenols decreased in the following rank order: EaE > ChE > CrE (Table 1).

Table 1: Total polyphenol content of S. sediforme extracts

\begin{tabular}{lc}
\hline Extract & $\begin{array}{c}\text { Total phenols content (mg AG- } \\
\text { Eq/g) }\end{array}$ \\
\hline CrE & $78.24 \pm 1.15$ \\
ChE & $100.54 \pm 1.78$ \\
EaE & $107.43 \pm 1.41$ \\
\hline
\end{tabular}

\section{Anti-inflammatory effect of $S$. sediforme extract}

The results showed that the edema weight of the control group was $7.26 \pm 0.15 \mathrm{mg}$, it was reduced by the diclofenac to $4.44 \pm 0.13 \mathrm{mg}$ and reduced by the $\mathrm{CrE} \mathrm{D}_{1}(12.5 \mathrm{mg} / \mathrm{Kg})$ and $\mathrm{D}_{2}(25 \mathrm{mg} / \mathrm{kg})$ to $4.66 \pm 0.23 \mathrm{mg}$ and $4.46 \pm 0.20 \mathrm{mg}$, respectively. The CrE of $S$. sediforme ( $D_{1}$ and $\left.D_{2}\right)$ present an inhibition percentage of inflammation (\%l) equal $35.81 \pm 3.18 \%$ and $38.57 \pm 2.80 \%$, respectively. The effect of the CrE was comparable to that of diclofenac used as a reference drug $(\% \mathrm{l}=38.84$ $\pm 1.87 \%$ ). However, the inhibition activity of $S$. sediforme extract is not significant $(p \leq 0.05)$ compared to the group treated with diclofenac. 


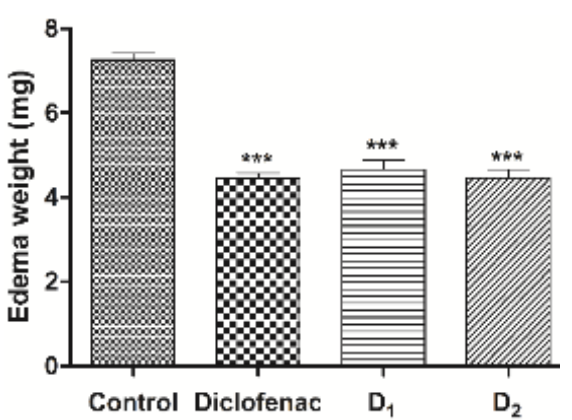

Figure 1: Anti-inflammatory effect of $S$. sediforme $\mathrm{CrE} ; \mathrm{D}_{1}$ and $\mathrm{D}_{2}$ (12.5 and $25 \mathrm{mg} / \mathrm{kg}$ dose, respectively) reduced ear edema induced by PMA in mice. Values are mean \pm SEM $(n=8)$. Comparisons of groups are made with respect to control group; ${ }^{* * *} p \leq 0.001$

\section{Superoxide scavenging activity}

Enzymatic assay (Cytochrome c test): Under the experimental conditions, the amount of $\mathrm{O}_{2}{ }^{*}$ generated by $X O$ per minute in the absence of extracts was $10.86 \pm 0.02 \mathrm{mM}$. The results showed that the scavenging effect of $S$. sediforme extracts was in a dose dependent manner (Figure $2 \mathrm{~A}$ ), this effect was decrease in the following order: $\mathrm{CrE}\left(\mathrm{IC}_{50}=0.063 \pm 0.005\right.$ $\mathrm{mg} / \mathrm{ml})$, ChE $(0.173 \pm 0.014 \mathrm{mg} / \mathrm{ml})$ and $\mathrm{EaE}$ $(0.425 \pm 0.002)$ (Figure $2 \mathrm{~B}$ ).
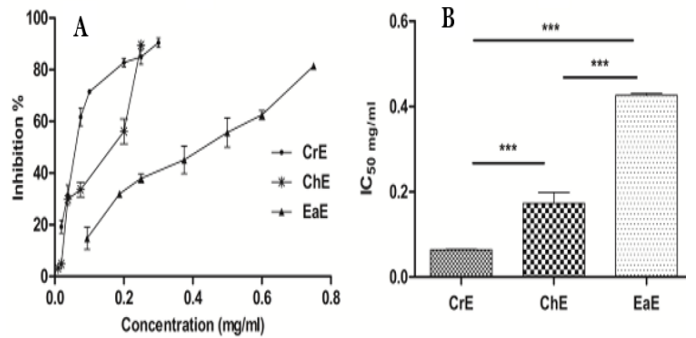

Figure 2: Superoxide scavenging activity of $S$. sediforme extracts using Cytochrome c test. Kinetic competition between the extracts and $\mathrm{O}_{2}{ }^{\cdot 2}$ generated by the xanthine/xanthine oxidase system (A), and the half maximal inhibition of cytochrome $\mathrm{C}$ activity concentration $\left(\mathrm{IC}_{50}\right)(\mathrm{B})$. Values are expressed as mean $\pm \operatorname{SD}(\mathrm{n}=3) ;{ }^{* * *} p \leq 0.001$

\section{Non-enzymatic activity}

The results showed that $S$. sediforme extracts had exhibited a scavenging activities in a dosedependent manner (Figure $3 \mathrm{~A}$ ). The lower $\mathrm{IC}_{50}$ value indicated the greater scavenging activity (Figure $3 \mathrm{~B}$ ), CrE had the strongest superoxide scavenging activity with $\mathrm{IC}_{50}$ equal $0.178 \pm 0.006$ $\mathrm{mg} / \mathrm{mL}$, followed by $\mathrm{ChE}$ and $\mathrm{EaE}(0.505 \pm 0.003$ and $0.515 \pm 0.002 \mathrm{mg} / \mathrm{mL}$, respectively).
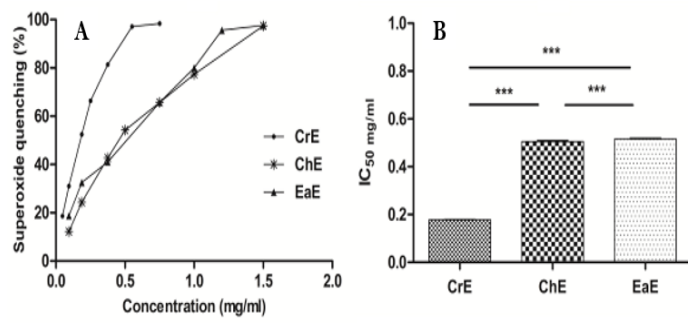

Figure 3: Superoxide quenching activity of $S$. sediforme extracts using NBT test. The kinetic of superoxide-scavenging effect $(\mathbf{A})$ and the inhibitory concentration of $50 \% \quad\left(\mathrm{IC}_{50}\right)(\mathrm{B})$, where $\mathrm{O}_{2}$ - $^{-}$was generated by NADH/PMS system. Values are expressed as mean \pm SD $(n=3) ;{ }^{* * *} p \leq 0.001$

\section{Metal chelating activity}

The effect of S. sediforme extracts on $\mathrm{Fe}^{2+}$ and ferrozine complex formation is shown in figure 4. The chelating ability of extracts increased with concentrations (Figure $4 \mathrm{~A}$ ). The inhibition of the formation of ferrous and ferrozine complex by $S$. sediforme extracts, indicate a chelating activity of ferrous ion before ferrozine. EDTA exhibited strong chelating ability of ferrous ion $\left(\mathrm{EC}_{50}=\right.$ $5.887 \pm 0.004 \mu \mathrm{g} / \mathrm{mL}$ ) compared with those of phenolics extracts (Figure $4 \mathrm{~B}$ ). ChE has an excellent chelating ability $\left(\mathrm{EC}_{50}=0.397 \pm 0.001\right.$ $\mathrm{mg} / \mathrm{mL})$, followed by EaE and $\mathrm{CrE}(0.526 \pm 0.047$ $\mathrm{mg} / \mathrm{mL}$ and $0.985 \pm 0.007 \mathrm{mg} / \mathrm{mL}$, respectively).
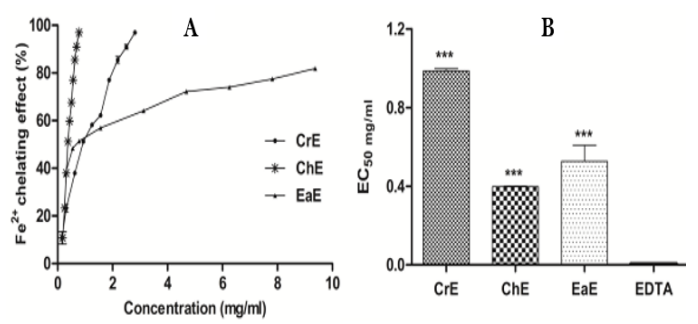

Figure 4: Ferrous iron-chelating ability of $S$. sediforme extracts. The kinetic of chelating effect of extracts (A) and $E_{50}$, effective concentration of extracts and EDTA for $50 \%$ of chelating activity (B). Results are expressed as mean \pm SD $(n=3)$. Comparison of extracts was realized against EDTA; ${ }^{* * *} p \leq 0.001$

\section{DISCUSSION}

High phenolic content of plants have been popularly used for the treatment of many diseases. Phenolic compounds such as phenolic acid and flavonoids possess diverse biological activities (anti-inflammatory and antiatherosclerotic activities) [12].

Application of PMA induced an inflammatory response and caused the activation of protein kinase $C(P K C)$ with a transient increase in 
prostanoid production associated [13]. This reaction reaches a maximum after few hours (6h) and subsides after $24 \mathrm{~h}$, multiple applications of PMA produce a more prolonged inflammatory response characterized by inflammatory cell influx, ear edema and epidermal cell hyperplasia [14]. In the present study, crude extract of $S$. sediforme showed an anti-inflammatory effect and reduced ear edema induced by PMA in mice. S. sediforme extract $\left(D_{1}\right.$ and $\left.D_{2}\right)$ achieved a high degree of anti-inflammatory activity, the two doses of CrE presented approximately the same degree of inhibition. However, the effect was comparable with that of diclofenac.

The superoxide anion is formed by the univalent reduction of triplet-state molecular oxygen $\left({ }^{3} \mathrm{O}_{2}\right)$. This process is mediated by redox-reactive compounds; enzymatically (NADPH oxidases and $\mathrm{XO}$ ) or non-enzymatically. A number of substances such as nitrate and oxygen can act as hydrogen acceptors for $\mathrm{XO}$; it has been mentioned that cytochrome $\mathrm{c}$ is also reduced by $\mathrm{XO} /$ cytochrome c system [15].

The superoxide scavenging activity of $S$. sediforme extracts was measured using the ability of these extracts to scavenge superoxide anion radicals $\left(\mathrm{O}_{2}{ }^{\cdot 2}\right)$ generated by the xanthine/xanthine oxidase system, the amount of generated superoxide was determined by measuring the reduction of cytochromec ${ }^{+3}$. CrE presents a strong superoxide scavenging capacity nearly, 3-folds and 7-folds higher than that of $\mathrm{ChE}$ and $\mathrm{EaE}$, respectively. Other researchers showed that $\mathrm{EaE}$ of Tamus comminus was the most potent scavenger of superoxide anion radical [16].

The inhibition of cytochrome $c$ reduction is due to dual effects of $S$. sediforme extracts. First, these compounds inhibit the XO activity and secondly, some compounds can scavenge superoxide radicals. In order to determine whether inhibition of cytochrome $c$ reduction was due to the inhibition of xanthine oxidase or to the superoxide scavenger activity, a non-enzymatic system of superoxide generation was used.

The non-enzymatic assay (NBT test) was based on the capacity of $S$. sediforme extracts to inhibit the reduction of NBT in the NADH-NBT-PMS system. In this system, the PMS-NADH coupling reaction reduces NBT and produce the superoxide anion from dissolved oxygen from [10]. The capacity of $\mathrm{CrE}$ to inhibit the reduction of NBT was approximately, 3-folds higher than that of ChE and EaE. Boumarfeg et al [17] have tested the extracts of Teucrium polium by the same test and the results demonstrated that this plant had a concentration-dependent manner scavenging activity by neutralizing superoxide radicals in the same order as shown in the results obtained by enzymatic method (Cyt $\mathrm{C}$ ). Synergic effect could be responsible for the improvement of these effects. This theory could explain the strong activity of CrE despite its low polyphenols content.

The important role of ferrous ions as catalysts of oxidative processes, leading to the formation of many free radicals via Fenton reaction. It is reported that the generated free radicals can cause the production of oxyradicals, lipid peroxidation and DNA damage. Ferrous ions $\left(\mathrm{Fe}^{2+}\right)$ chelating molecules may cause important antioxidative effects by retarding metal-catalyzed oxidation [18]. The formation of the colored complex, Ferrous with Ferrozine, was disrupted by chelating agent leading to a decrease of color [11].

Ethylenediaminetetraacetic acid (EDTA) can chelate ferrous ion in the center and block the $\mathrm{Fe}^{2+}$-ferrozine complex formation [19]. Polyphenolic compounds should be able to chelate transition metals because of the high charge density of the phenoxide group generated on deprotonation [20]. ChE of $S$. sediforme contains a high content of polyphenols and its strong activity could be explained by the aglycone nature of its flavonoids.

\section{CONCLUSION}

The CrE of S. sediforme present a powerful in vivo anti-inflammatory effect. The treatment of mouse skin with a PKC activator, such as PMA, induces the formation of free radicals and for that reason the in vitro antioxidant effect of $S$. sediforme extracts was evaluated. The examined extracts have a high scavenging activity for the superoxide anion in vitro using xanthine/xanthine oxidase system. However, this activity of $S$. sediforme extracts may be due to the enzymatic inhibition and/or superoxide scavenger effect, for this reason an NBT assay was carried out to prove the scavenging effect of this plant. All extracts showed a moderate ferrous ion chelating ability. These results could represent an important contribution for the understanding of the anti-inflammatory effects of this plant and its use in the traditionally medicine.

\section{DECLARATIONS}

\section{Acknowledgement}

This work was supported by the Algerian Ministry of Higher Education and Scientific Research

Trop J Pharm Res, October 2020; 19(10): 2113 
(MESRS, DGRSDT) and by the Thematic Agency of Science Research in Health (ATRSS).

\section{Conflict of interest}

No conflict of interest is associated with this work.

\section{Contribution of authors}

We declare that this work was done by the authors named in this article and all liabilities (Laboratory of Applied Biochemistry, Faculty of Nature and Life Sciences, Univ. Setif) pertaining to claims relating to the content of this article will be borne by the authors.

\section{Open Access}

This is an Open Access article that uses a funding model which does not charge readers or their institutions for access and distributed under the terms of the Creative Commons Attribution License (http://creativecommons.org/licenses/by/ 4.0) and the Budapest Open Access Initiative (http://www.budapestopenaccessinitiative.org/rea d), which permit unrestricted use, distribution, and reproduction in any medium, provided the original work is properly credited.

\section{REFERENCES}

1. Zhang K, Kaufman RJ. From endoplasmic-reticulum stress to the inflammatory response. Nature 2008; 454: 455-462.

2. Guzik TJ, Korbut R, Adamek-Guzik T. Nitric oxide and superoxide in inflammation and immune regulation. $\mathrm{J}$ Physiol Pharmacol. 2003; 54 (4): 469-487.

3. Titretir S, Sakar MK, Berkman MZ. Determination of Some Cations in Sedum album and Sedum sediforme. Acta Pharm Turcica 2004; 46: 61-65.

4. Gay WI. Methods of animal experimentation (Vol-I). New York: Academic Press; 1965; pp 32-191.

5. Markham KR. Techniques of flavonoid identification. London: Academic Press; 1982; pp 1-113.

6. Li HB, Cheng KW, Wong CC, Fan KW, Chen F, Jiang $Y$. Evaluation of antioxidant capacity and total phenolic content of different fractions of selected microalgae. Food Chem 2007; 102: 771-776.

7. Garridoa G, Gonzalez D, Lemus Y, Delporte C, Delgadoa $R$. Protective effects of a standard extract of Mangifera indica $L$. against mouse ear edemas and its inhibition of eicosanoid production in $\mathrm{J774}$ murine macrophages. Phytomed 2006; 13: 412-418.
8. Selloum L, Reichl S, Müller M, Sebihi L, Arnhold, J. Effects of flavonols on the generation of superoxide anion radicals by xanthine oxidase and stimulated neutrophils. Arch Biochem Biophys 2001; 395 (1): 4956.

9. Baghiani A, Harrison R, Benboubetra M. Purification and partial characterisation of camel milk xanthine oxidoreductase. Arch Physiol Biochem 2003; 111: 407414.

10. Ani V, Varadaraj MC, Akhilender NK. Antioxidant and antibacterial activities of polyphenolic compounds from bitter cumin (Cuminum nigrum L.). Eur Food Res Technol 2006; 224: 109-115.

11. Le K, Chiu F, Ng K. Identification and quantification of antioxidants in Fructus lycii. Food Chem. 2007; 105: 353-363.

12. Li HB, Wong CC, Cheng KW, Chen F. Antioxidant properties in vitro and total phenolic contents in methanol extracts from medicinal plants. Lebenson Wiss Technol 2008; 41: 385-390.

13. Kang JY, Khan MNA, Park NH, Cho JY, Lee MC, Fujii H, Hong $Y K$. Antipyretic, analgesic, and anti-inflammatory activities of the seaweed Sargassum fulvellum and Sargassum thunbergii in mice. J Ethnopharmacol 2008; 116: 87-190.

14. Malaviya $R$, Ansell J, Hall L, Fahmy M, Argentieri RL, Olini Jr GC, Pereira DW, Sur R, Cavender D. Targeting cytosolic phospholipase A2 by arachidonyl trifluoromethyl ketone prevents chronic inflammation in mice. Eur J Pharmacol 2006; 539: 195-204.

15. Horecker BL, Heppel LA. The reduction of cytochrome $c$ by xanthine oxidase. J Biol Chem 1949; 178: 683-690.

16. Boumarfeg S, Baghiani A, Messaoudi D, Khennouf S, Arrar L. Antioxidant properties and xanthine oxidase inhibitory effects of Tamus communis $L$. root extracts. Phytother Res 2009; 23: 283-288.

17. Boumarfeg S, Baghiani A, Djarmouni M, Ameni D, Adjadj M, Belkhiri F, Charef N, Khennouf S, Arrar L. Inhibitory activity on xanthine oxidase and antioxidant properties of Teucrium polium L. extracts. Chin Med 2012; 3: 3041.

18. Gülçin I, Huyut Z, Elmastas M, Aboul-Enein HY. Radical scavenging and antioxidant activity of tannic acid. Arabian J of Chem 2010; 3: 43-53.

19. Luo W, Zhaoa M, Yang B, Rena J, Shend G, Rao G. Antioxidant and antiproliferative capacities of phenolics purified from Phyllanthus emblica L. fruit. Food Chem 2011; 126(1): 277-282.

20. Lantto TA, Dorman HJD, Shikov AN, Pozharitskaya ON, Makarov VG, Tikhonov VP, Hiltunen R, Raasmaja A. Chemical composition, antioxidative activity and cell viability effects of a Siberian pine (Pinus sibirica Du Tour) extract. Food Chem 2009; 112: 936-943.

Trop J Pharm Res, October 2020; 19(10): 2114 